\title{
Facility layout problem: Bibliometric and benchmarking analysis
}

\author{
G. La Scalia ${ }^{a^{*}}$, R. Micale ${ }^{a}$ and M. Enea ${ }^{a}$
}

${ }^{a}$ Department of Engineering - University of Palermo, Viale delle Scienze, bld. 8, 90128 - Palermo -Italy

\begin{tabular}{l}
\hline C H R O N I C L E \\
\hline Article history: \\
Received March 32019 \\
Received in Revised Format \\
April 22019 \\
Accepted May 62019 \\
Available online \\
May 62019 \\
\hline Keywords: \\
Facility Layout Problem \\
Bibliometric analysis \\
Instances \\
Benchmarking procedure
\end{tabular}
A B S T R A C T

Facility layout problem is related to the location of departments in a facility area, with the aim of determining the most effective configuration. Researches based on different approaches have been published in the last six decades and, to prove the effectiveness of the results obtained, several instances have been developed. This paper presents a general overview on the extant literature on facility layout problems in order to identify the main research trends and propose future research questions. Firstly, in order to give the reader an overview of the literature, a bibliometric analysis is presented. Then, a clusterization of the papers referred to the main instances reported in literature was carried out in order to create a database that can be a useful tool in the benchmarking procedure for researchers that would approach this kind of problems.

\section{Introduction}

Facility Layout Problem (FLP) is defined as the finding of the most efficient departments arrangement on a plant area subject to different constraints in order to satisfy one or more objectives (Heragu, 1997). An effective facility layout design contributes to reduce the operating costs (Tompkins et al., 1996). Hence, the FLP still attracts the attention of many researchers in the field of production management and industrial engineering. A recent literature survey provided a general overview of the research conducted on the FLPs (Hosseini-Nasab et al., 2018) in which the main features that characterize the problem were identified and classified. In particular, the main classification is about the layout evolution from the static to the dynamic approach (Koopmans \& Beckmann, 1957; Kouvelis et al., 1992). When the flow of materials between facilities does not change over time, the problem is known as the Static Facility Layout Problem (SFLP), while when material flows vary, the SFLP becomes a Dynamic Facility Layout Problem (DFLP). Another important classification regards the type of input data, such as the area of each department, the material flows between departments and the material handling costs. However, the assumption that this information is available in advance is not realistic in several conditions. For this reason, methodologies able to manage the uncertainty of these data were recently developed (Drira et al., 2013; Nematian, 2014; Kaveh et al., 2014; Neghabi et al., 2014). Moreover, it must be pointed out that the solutions referred to a single objective (i.e. material handling cost only) cannot be compared with

* Corresponding author

E-mail: giada.lascalia@unipa.it (G. La Scalia)

2019 Growing Science Ltd.

doi: $10.5267 /$ j.ijiec.2019.5.001 
those referred to the multi-object context in which other qualitative factors, such as adiacence or distance rating between departments, plant safety, and flexibility of layouts for future design changes, are also considered (Jolai et al., 2012; Aiello et al., 2013; Azevedo et al., 2017). These above-mentioned features vary from one application to the other thus making the benchmarking of the performance of each approach a tough issue (Aiello et al., 2013). Hence, to evaluate the performance of different approaches, the results have to be compared with those obtained from previous literature researches characterized by the same layout evolution, the same input data and the same objective functions. The comparison is usually made on the basis of a set of instances in which different setups of the FLP are reported. However, in many articles there is a gap in the benchmarking procedure due to the use of random data set or real cases setup. Referred to a real case study it is generally justified only when dealing with an extremely innovative problem for which there are no references in literature. The robustness of the approach proposed strongly depends on the above considerations and for this reason a database of the instances present in literature and of the papers referred to the same instances for each class of problems is here proposed. This paper reviews the research progress on the FLP in the last 60 years and focuses on the benchmarking procedure adopted in terms of instances used. We collect papers belonging to the same class of problems and we identify those referred to the same instances. This is the first time in which a bibliometric analysis is conducted on the FLP and it represents a framework of the main indicators that characterize publications in this field. The present paper is structured as follows. Section 2 describes the methodology for showing a general overview on the research trends in the last sixty years. Section 3 reports the analysis of the papers presented in the previous section in terms of instances adopted for the benchmarking procedure. Finally, the paper ends with the Conclusions in Section 4 identifying potential gaps in literature and proposing new research topics.

\section{Data and methodology}

The dataset for this study was retrieved searching "Facility layout problem" in the field article title, abstract, keywords of Scopus, which is one of the most widely used search engine among the scientific community. The time horizon from 1963 to 2019 was selected. Among all types of publications, we limited this study to the articles and reviews wrote in English on journals considering 5 subject areas (Engineering, Computer Science, Decision Sciences, Business Management and Accounting and Mathematics) obtaining a sample database of 922 works. Then, such database was exported and analysed through the freely available software VOSviewer, for the construction and the visualization of bibliometric maps (Van Eck and Waltman, 2010). This software is able to draw bibliometric distancebased maps, giving attention to their graphical presentation facilitating the comprehensibility.

\subsection{Geographical landscape}

Fig. 1 shows the evolution of the concentration of the papers in three different time windows (1963-1983; 1984-2004; 2005- 2019). In particular, the number of countries in which research on the FLP was conducted is almost quadrupled from 1963 to today. We have considered papers that are cited at least once and countries with a minimum number of 10 publications. Under these assumptions, in the first time window, only 4 countries meet the thresholds whereas in the second and in the third one the number of countries becomes 13 and 15 respectively. This trend confirms the importance of the FLP and the interest of many researches in this field.

In particular in the last decade the most prolific countries are India, Iran and USA, followed by Canada, China and Italy. 


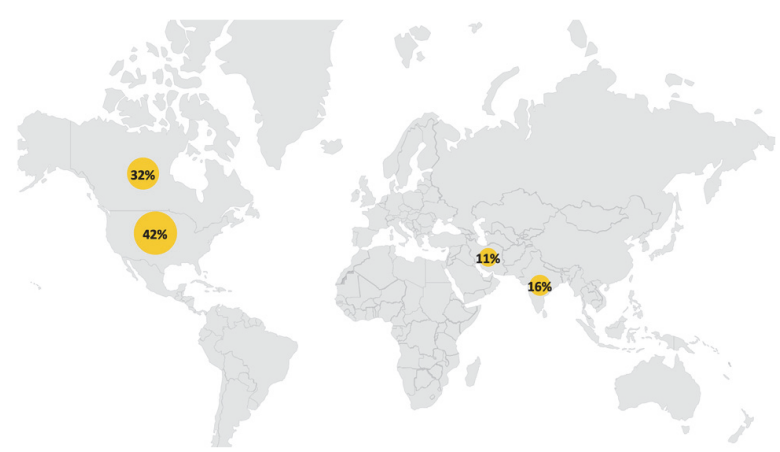

(a)

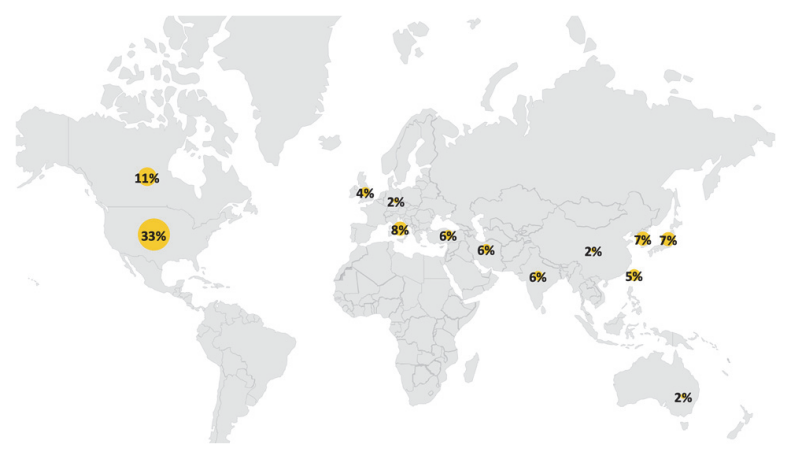

(b)

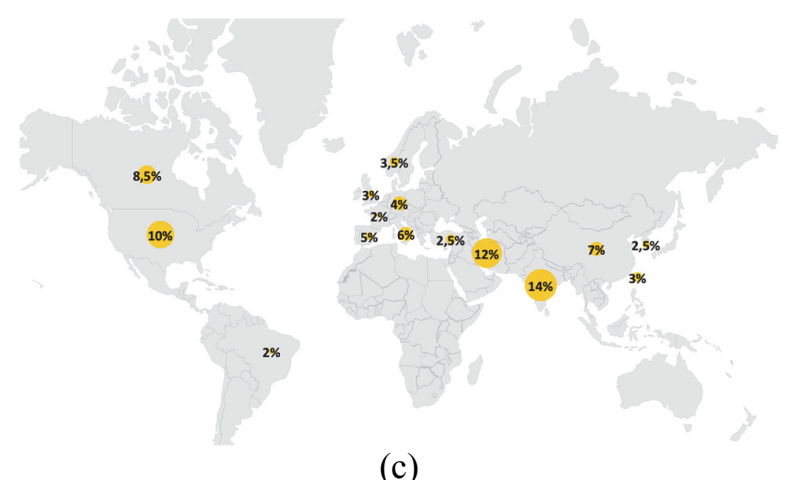

Fig. 1. Geographic landscape a) 1963-1983; b) 1984-2004; c) 2005- 2019

\subsection{Research trends}

To identify the main research trends over the last two decades, we conducted a co-occurrence analysis of all the keywords in the database.

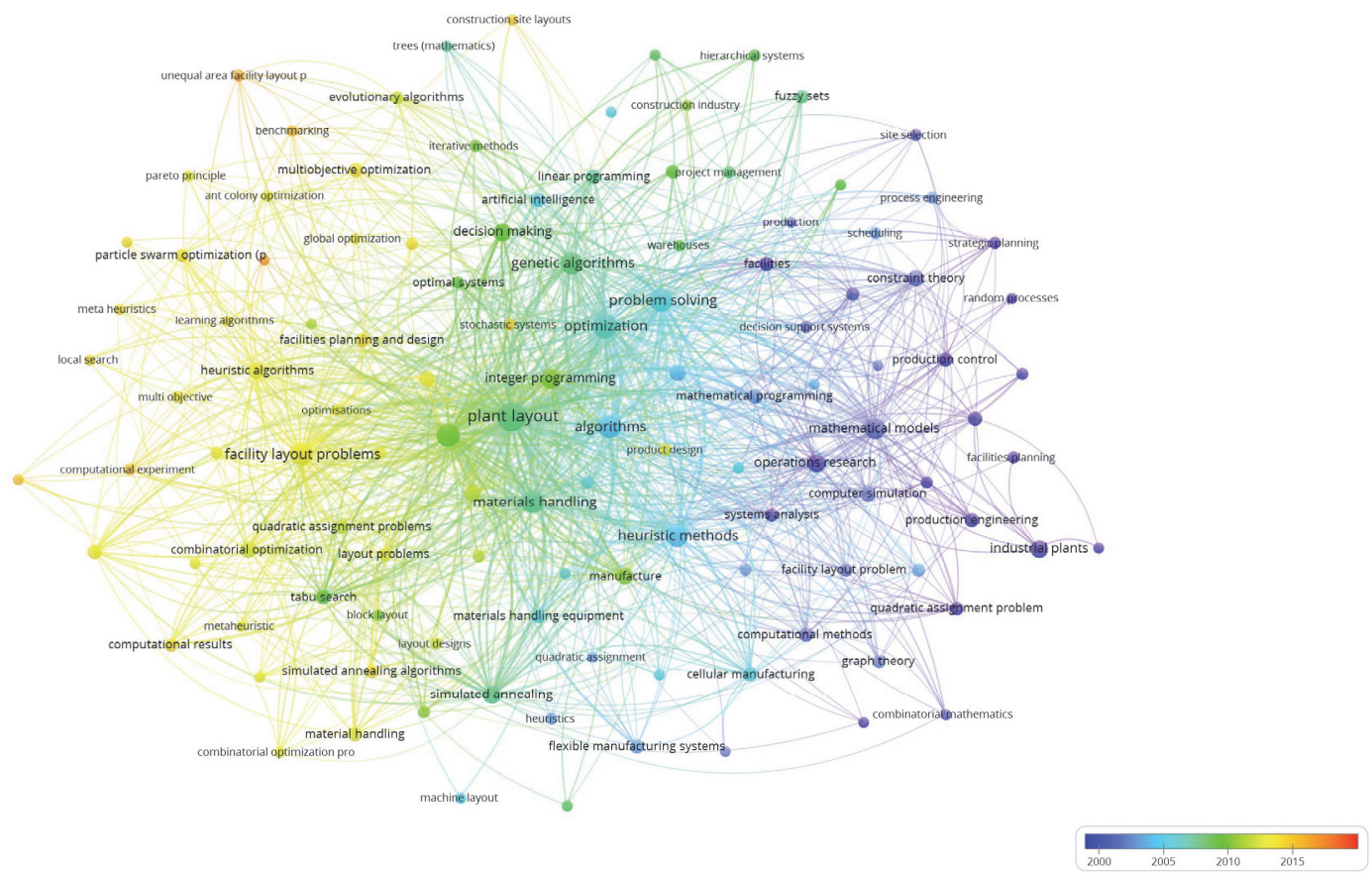

Fig. 2. Keywords map 
Results are shown in Fig. 2, where the relatedness between items is calculated with respect to the number of documents in which they occur together. We set a threshold to 10 as the minimum number of occurrences and we limit the set to the most connected keywords. We obtain a total number of 117 keywords. However, some terms in the map result duplicated. Particularly, VOSviewer does not distinguish among singular and plural. Therefore, to overcome this problem, we removed manually four of these keywords that correspond to the ones with a lower weight. All the other settings are given by default. The distance among items was calculated on the basis of the association strength (Van Eck \& Waltman, 2010), representing the ratio between the number of co-occurrences of term $i$ and term $j$ and the total number of occurrences of $i$ multiplied for the total number of occurrences of $j$. The higher the association strength between two nodes of the network is, the shorter their distance is. The colour scale refers to the average year of publications. Therefore, Fig. 2 provides an overview of the most cited keywords over the last twenty years, enabling to infer the most debated research topics. On the basis of the map of keywords, the identified research trend shows an increasing interest in solving dynamic facility layout problems based on meta-heuristic and evolutionary approaches (Tayal \& Singh, 2018; Turanoğlu \& Akkaya, 2018). Moreover, the last researches involved multi-objective optimization approachs paying attention to the instances-based benchmarking procedure (Liu \& Liu, 2019; Liu et al., 2018; Samanta et al., 2018; La Scalia et al., 2019).

\subsection{Citations overview}

The sample of 922 publications receives in total 22,003 citations of which 15,380 in the last ten years. In this research we have used the tool available on Scopus for analysing these documents in terms of citations, authors and sources over the years. Fig. 3 refers to the last decade and shows a general increasing trend, in particular 2018 is the year with the highest number of citations.

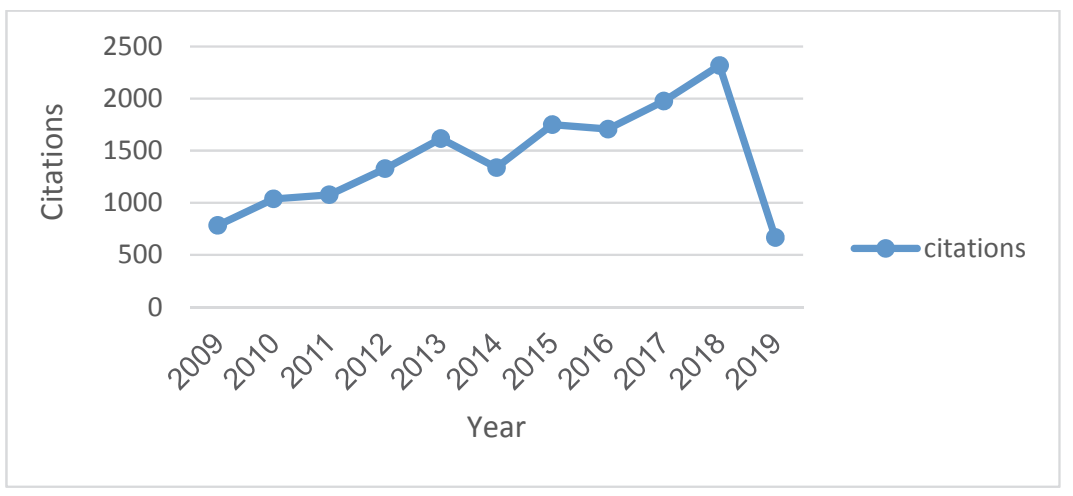

Fig. 3. Citations overview in the last ten years

The same year results the most prolific with 58 papers published (Fig. 4).

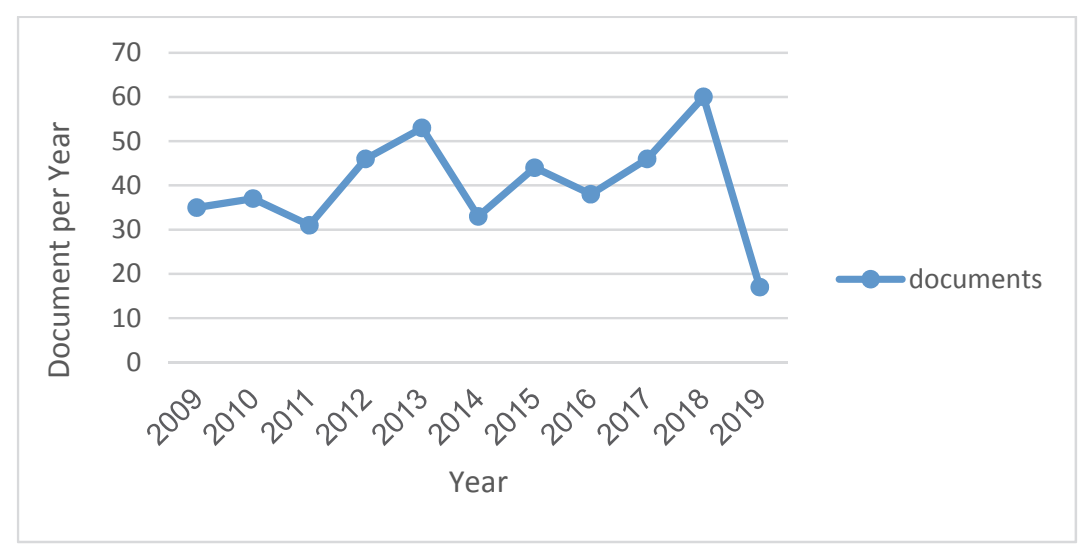

Fig. 4. Documents by years (2009-2019) 
Finally, Fig. 5 shows the citation map, whose purpose is to identify the most prolific authors publishing in the field of the FLP. To explore the authors' landscape, we conduct a citation analysis, given the widespread assumption that the number of citations reflects the publication's notoriety and, therefore, the influence of an author's work (Van Nunen et al., 2017). The software Vos Viewer was set considering a minimum number of documents for each author equal to 1 and a minimum number of citations of 50 . In this map, the size of the bubble, relative to a given author, is determined by the number of publications. The link reflects, instead, which authors have worked on the same work, whereas the colour shows the average number of citations that the publication received from the other authors in the map. In particular, the colour red corresponds to an average number of citations of more than 150 , whereas the colour blue corresponds to a number inferior to 20 . Moreover, the distance between two authors reflects the tendency of these authors to cite each other.

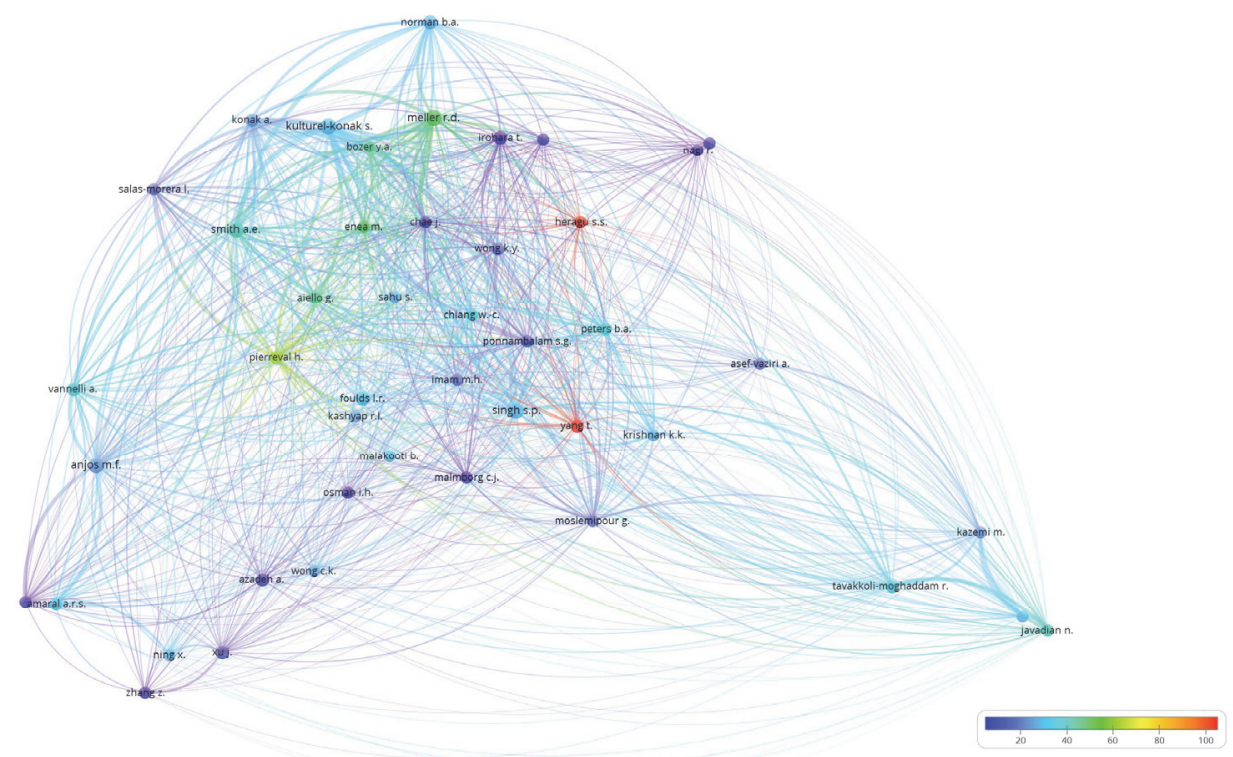

Fig. 5. Citations map

On the basis of these assumptions, the most significant papers in terms of citation belong to three authors: SS. Heragu, T. Yang and H Pierraval. Table 1 reports the most relevant contributions, according to the number of citations indicated by the Scopus database. The table also indicates the research areas, which are: Engineering (E), Mathematic (M), Computer Science (CS), and Decision Science (DS).

Table 1

Main references on FLP

\begin{tabular}{lll}
\hline Reference & Citation & Research area \\
\hline Kusiak \& Heragu, 1987 & 407 & M,DS \\
Yang \& Hung, 2007 & 259 & M, E, CS \\
Drira, Pierreval and Hajri-Gabouj, 2007 & 340 & E, CS \\
\hline
\end{tabular}

\subsection{Journals}

Fig. 6 shows the landscape of journals included in the sample database. To obtain this map, we conducted a bibliographic coupling analysis, where the number of references they share determines the relatedness between two journals. To calculate the weight of a connection between two items we used the fractional counting, which weights their relationship according to the number of references they share with other journals. The map includes only those journals that published at least 5 papers and that have at least 20 citations. We have considered a time window of the last two decades and 33 journals belonged to the interval. 


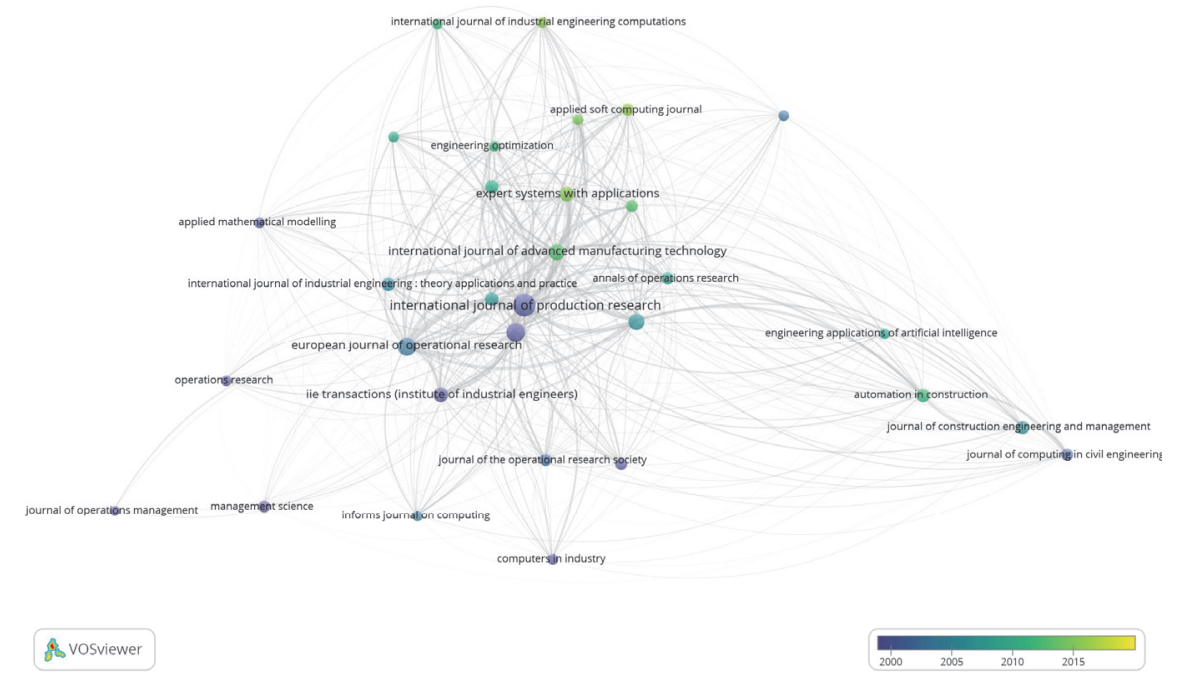

Fig. 6. Journals map

Each journal has a colour that indicates the average publication date. The more the colour tends to yellow, more recent the publications are. The font size and the dimension of the bubble in the figure represent the number of publications, whereas links represent the citations obtained in other journals.

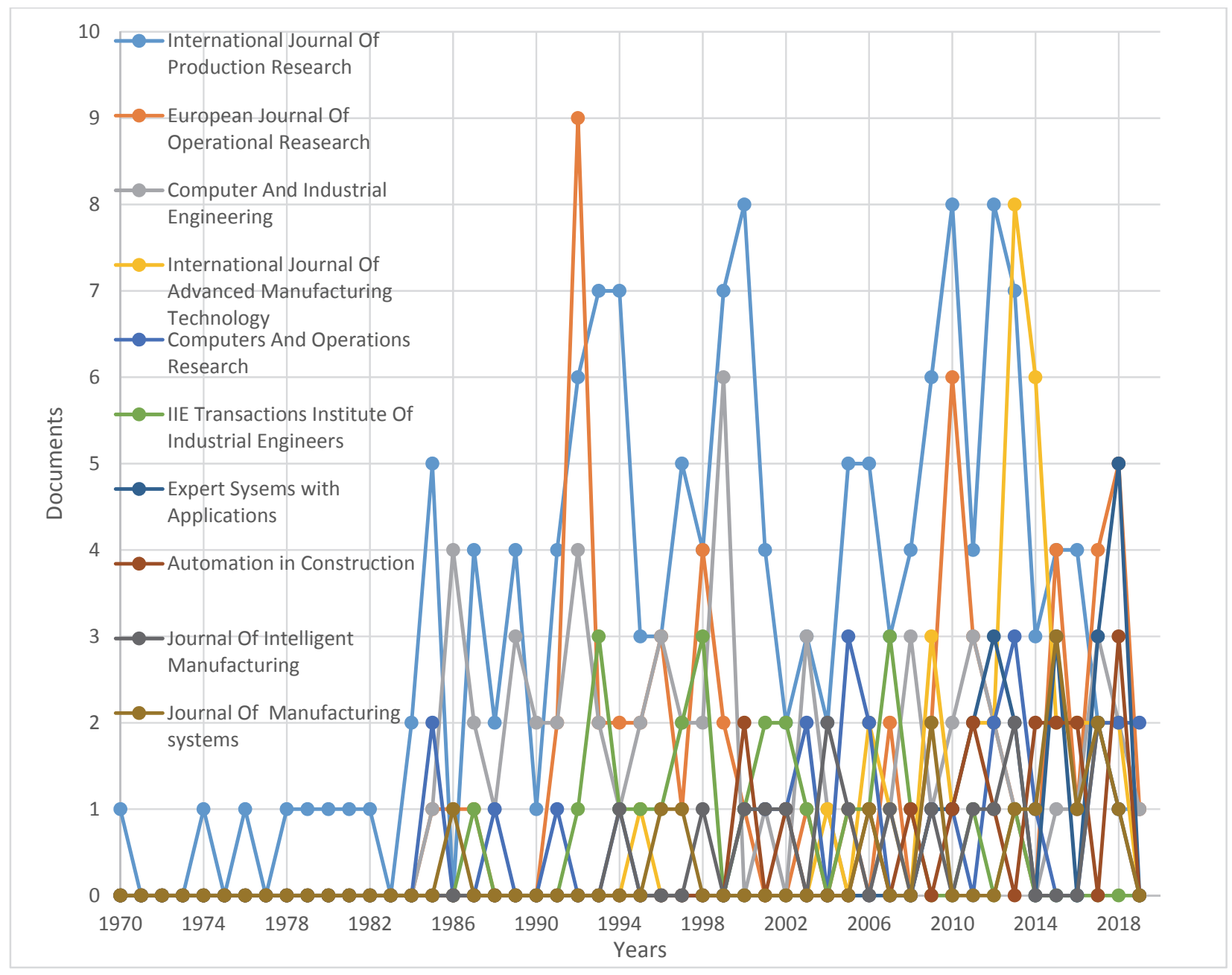

Fig.7. Documents per year by source (1963-2019) 
As instance, the International Journal of Production Research, with 155 published papers, is located in the centre of the map because of the high number of citations in the other journals present in the same map. We have refined these results using the analyser tool of scopus, comparing the 10 most prolific journals on the whole time horizon (1963-2019) with those that have most documents in the last ten years. Results are reported in the following figures (Fig. 7 and Fig. 8).

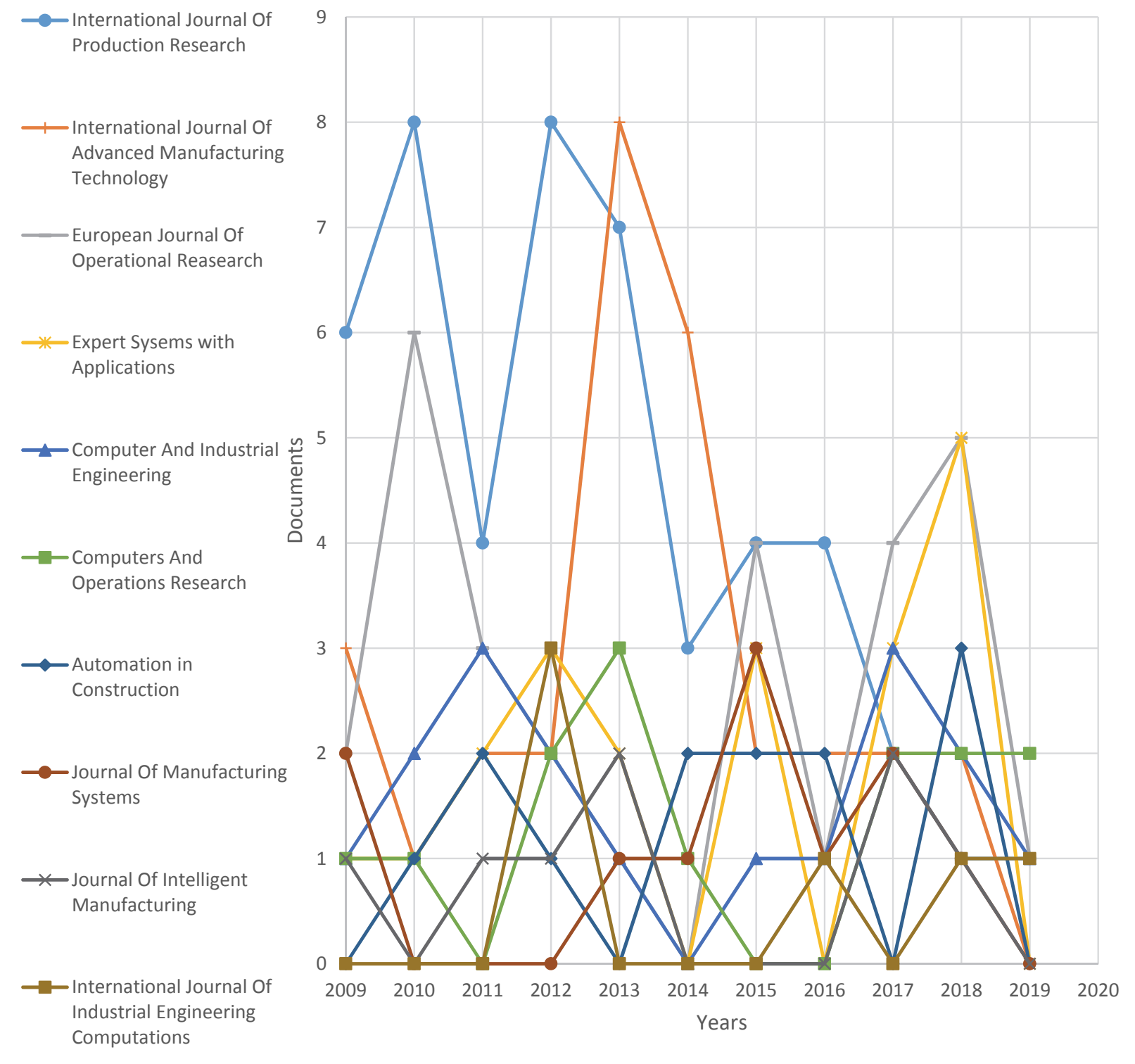

Fig. 8. Documents per year by source (2009-2019)

The comparison between the above figures shows that, in the last decade, the only change in the top ten of the most prolific journals on FLP is represented by the introduction of International Journal of Industrial Engineering Computations.

\section{General overview of the benchmarking procedure}

The benchmarking analysis applied to the facility layout problem consists in comparing the results obtained with the proposed approach with those present in literature to prove the achieved improvement. 
In this section we have analysed the paper involved in this research in order to show how many papers adopt a benchmarking procedure in their approach. Figure 9 shows that only $60 \%$ of the published papers on the SFLP make comparisons, complete or partial, on instances present in literature. Of the remaining $40 \%, 15 \%$ refers to a real case study and $25 \%$ to randomly generated data sets.

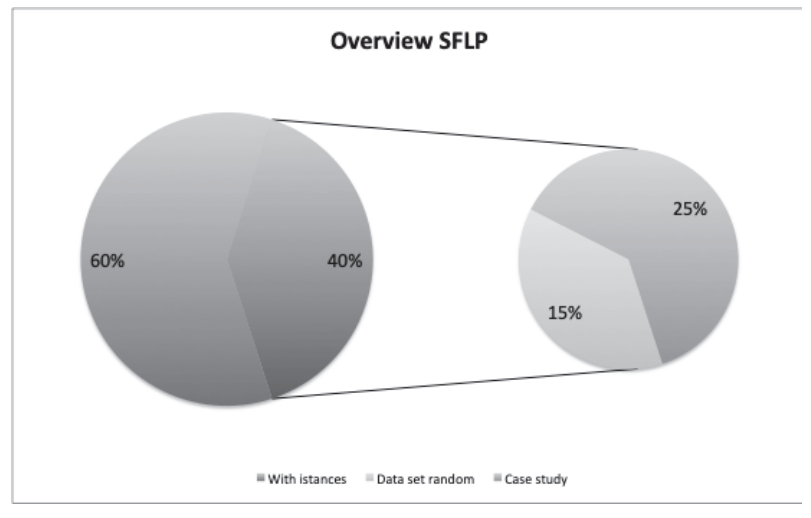

Fig. 9. General overview SFLP

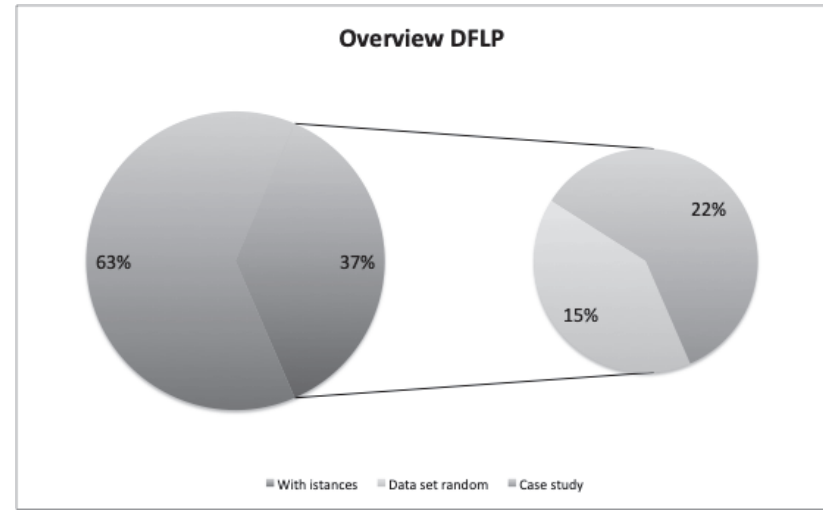

Fig. 10. General overview DFLP

For DFLP (Fig. 10), only 63\% of published articles make comparisons, complete or partial, on instances present in literature. Of the remaining $37 \%, 15 \%$ refers to a real case study and $22 \%$ to randomly generated data sets. To carry out benchmarking operations it is necessary to refer to the same instance. This aspect is what pushed to present the instances used in literature, subdivided in static and dynamic problems. Then for each instance a cloud of papers was built subdividing them on the basis of the type of objective function used (single or multi) and the type of data used (deterministic or stochastic). Tables 2 and 3 report the instances for the DFLP and the SFLP respectively.

Table 2

Instances for the DFLP

\begin{tabular}{|c|c|c|}
\hline Instance & Papers single objective & Papers multi objectives \\
\hline Approach & Deterministic & Deterministic Stochastic \\
\hline $\begin{array}{l}\text { P6 and P12 department } \\
\text { problem (Dunker, Radons, } \\
\text { Westkämper, 2003; Yang } \\
\text { \& Peters, 1998) }\end{array}$ & $\begin{array}{l}\text { Kulturel-Konak \& Konak, 2015; } \\
\text { Mckendall \& Hakobyan, } \\
\text { Derakhshan \& Wong, 2017. }\end{array}$ & Jolai et al., 2012. \\
\hline $\begin{array}{l}6, \quad 15, \quad 30 \text { departments } \\
\text { problems (Conway \& } \\
\text { Venkataramanan, 1994) }\end{array}$ & $\begin{array}{l}\text { Baykasoglu, \& Gindy, 2001; Pillai et al., } \\
\text { 2011; McKendall et al., 2006; } \\
\text { Baykasoglu et al., 2006; Balakrishnan \& } \\
\text { Cheng, 2000; Erel et al., 2003; } \\
\text { Balakrishnan et al., 2003; McKendall \& } \\
\text { Shang, 2006; Ulutas \& Islier, 2009; } \\
\text { Sahin et al., 2010; Azimi \& Charmchi, } \\
\text { 2012; Chen, 2013; Hosseini-Nasab \& } \\
\text { Emami, 2013; Saberi \& Azimi, 2013; } \\
\text { Pourvaziri \& Naderi, 2014; Hosseini et } \\
\text { al., 2014. }\end{array}$ & $\begin{array}{lll}\text { Bozorgi } \\
\text { al., } 2015\end{array} \quad$ et $\begin{array}{l}\text { Ripon } \\
2011 b\end{array}$ et $\quad$ al., \\
\hline $\begin{array}{l}6,12,20,30 \text { departments } \\
\text { problem (Lacksonen \& } \\
\text { Enscore, 1993) }\end{array}$ & $\begin{array}{l}\text { McKendall \& Shang, 2006; } \\
\text { Kaku \& Mazzola,1997. }\end{array}$ & Bozorgi et al., 2015 \\
\hline Pr1 (Rosenblatt, 1986) & $\begin{array}{l}\text { Baykasoglu \& } \begin{array}{l}\text { Gindy, } \\
\text { 2001; Conway } \quad \&\end{array} \\
\text { Venkataramanan, } 1994 ; \\
\text { Ulutas \& Islier, 2009. }\end{array}$ & Azevedo et al., 2017. \\
\hline $\begin{array}{l}\text { Pr2 (Conway \& } \\
\text { Venkataramanan, 1994) }\end{array}$ & Ulutas \& Islier, 2009. & \\
\hline
\end{tabular}



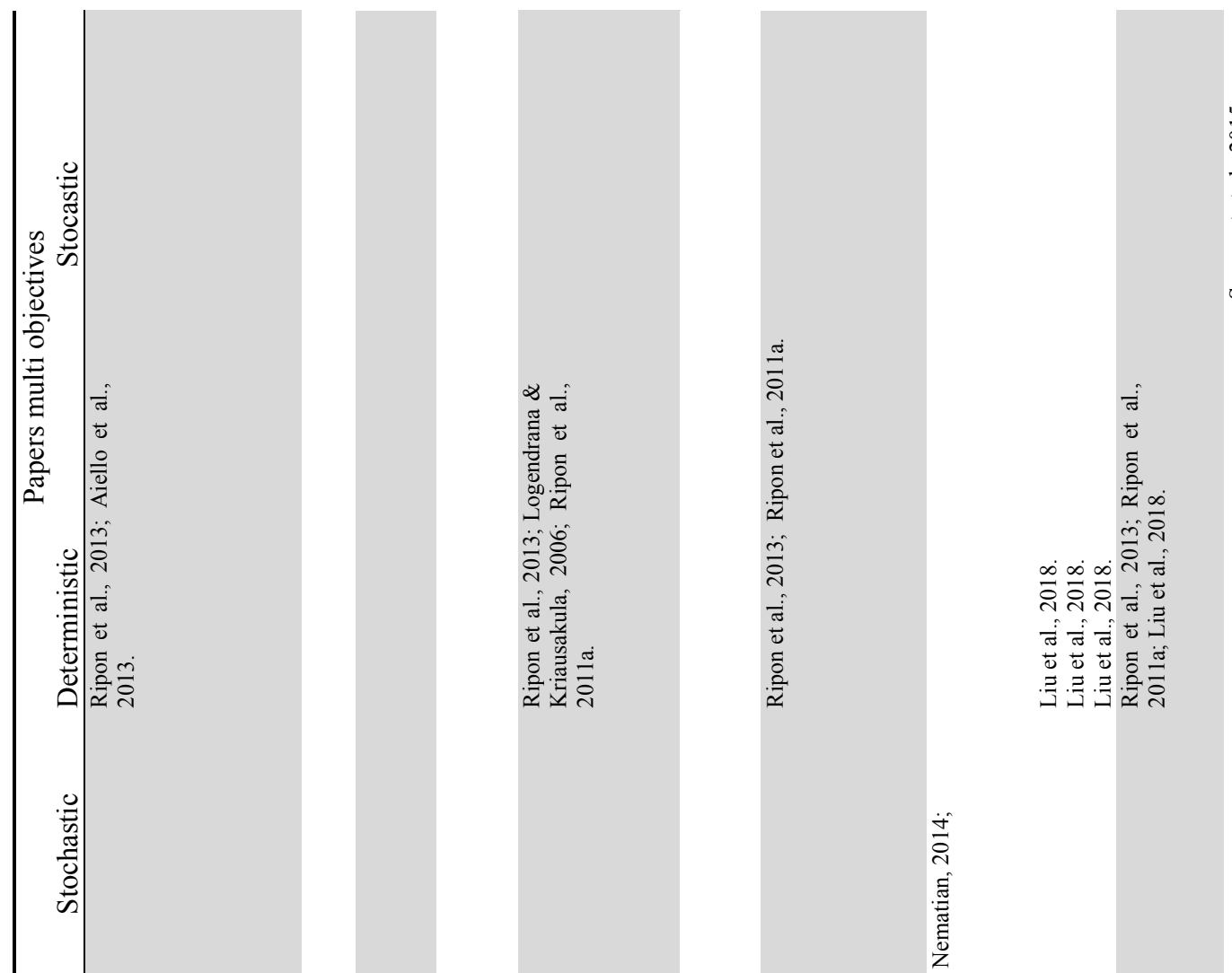

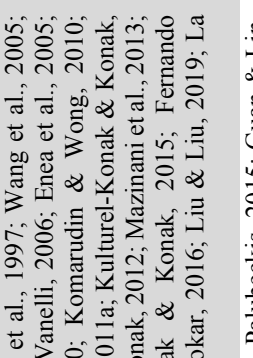

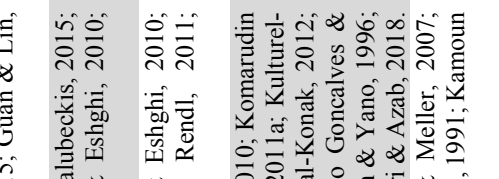

(1)

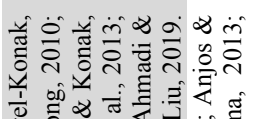

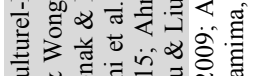

\& 0

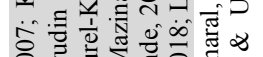

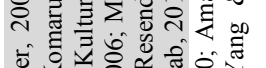

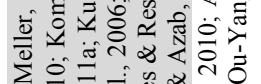

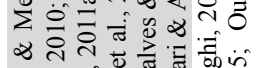

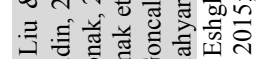

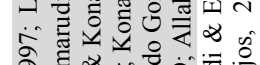

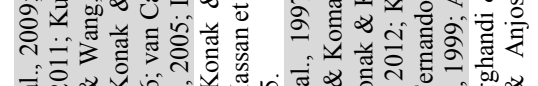

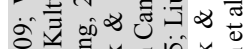

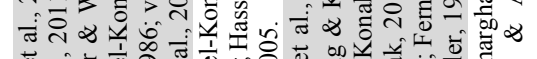

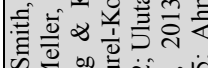

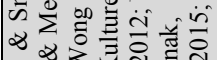

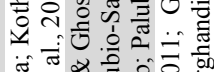

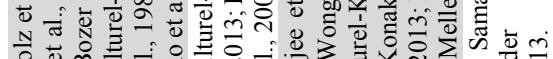

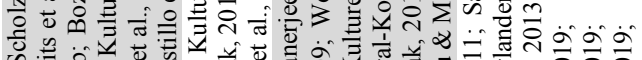

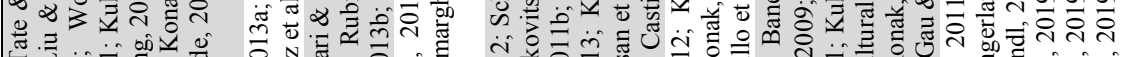

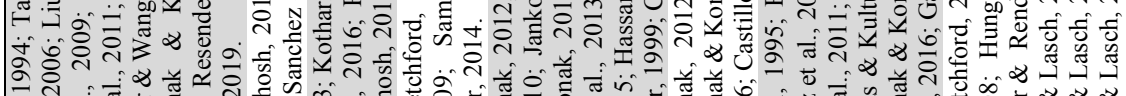

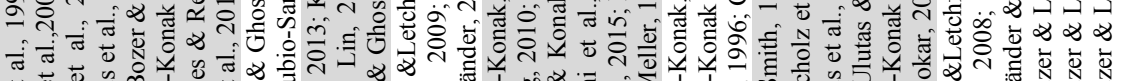

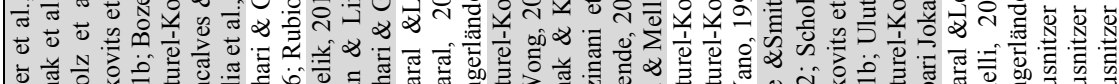

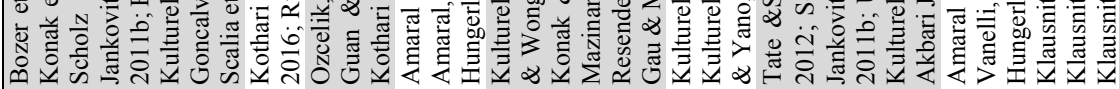

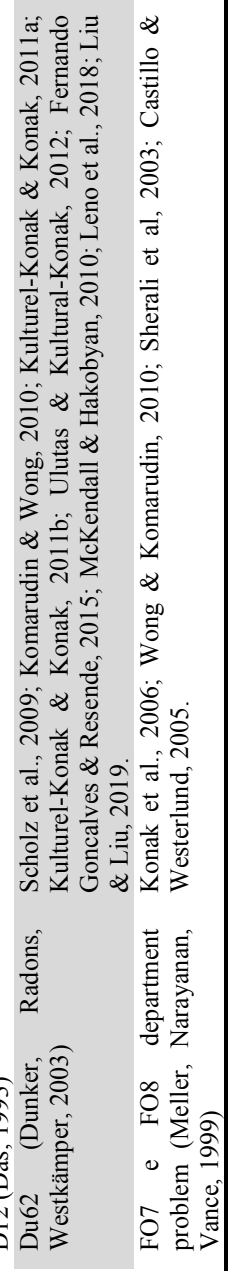




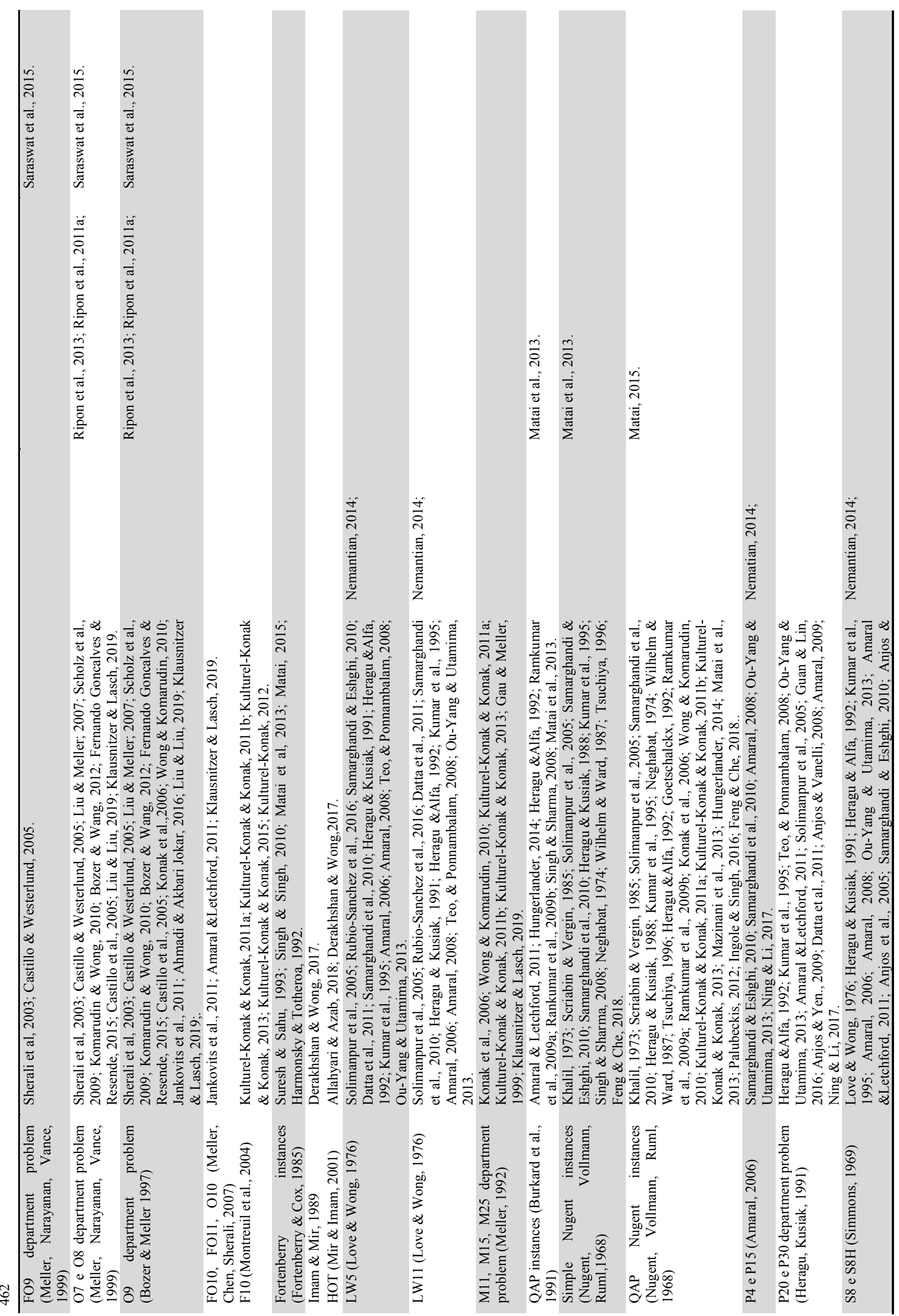




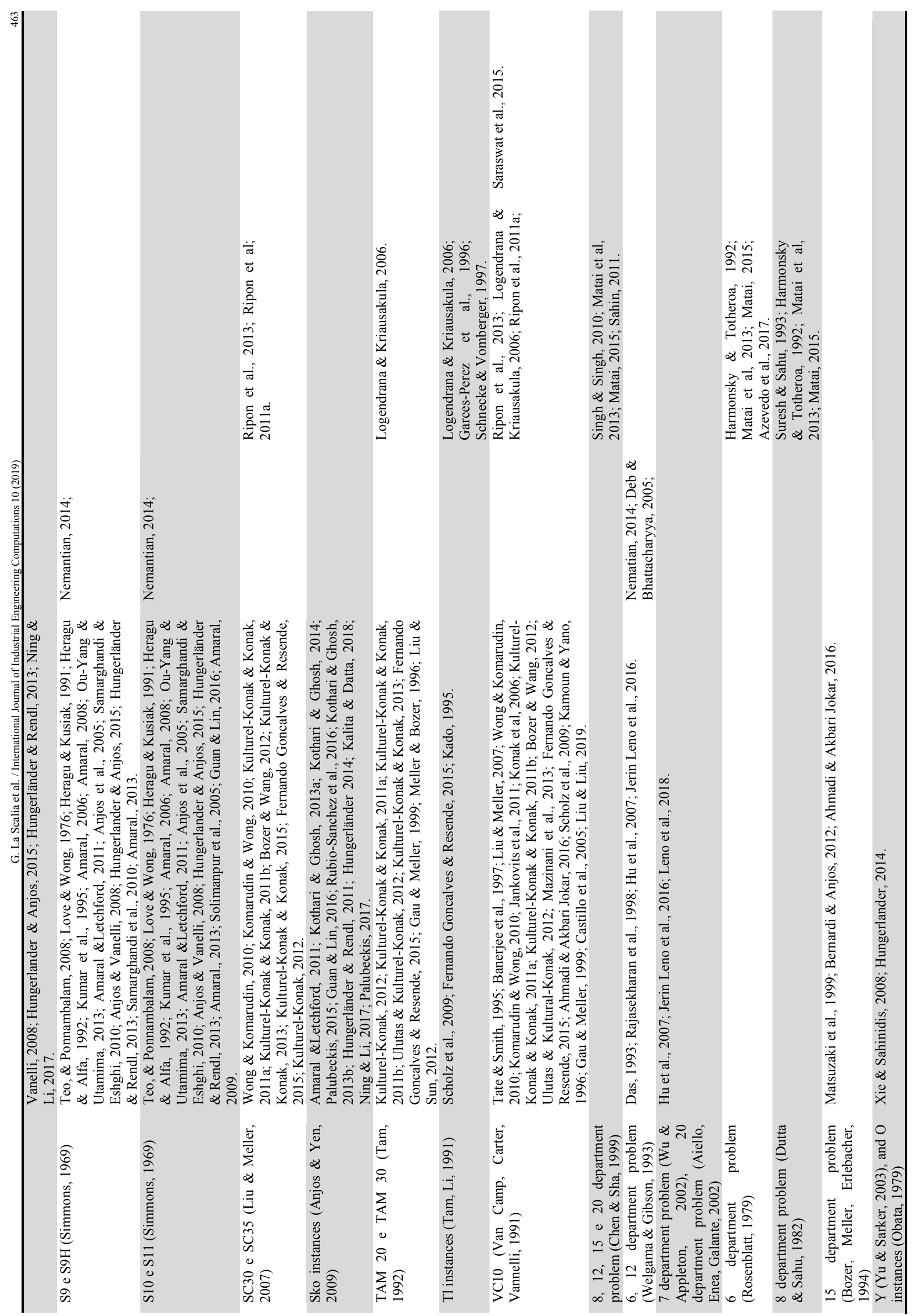




\section{Conclusions}

This paper explores the extant literature on the "Facility Layout Problem" to identify the main research trends over the last decades. Moreover, the analysis of the keywords allows to visualize the past research trends, and could even support researchers in the identification of potential gaps in literature. In particular, the distance among nodes in the map could show unexplored connections among research topics, whereas the bubble size could indicate a still little debated topic. As instance, future research could involve multi objective approaches, as well as the use of evolutionary methods to solve the FLP. The aim of the following research is also to offer a valid tool for identifying all the papers related to a specific instance in order to optimize the benchmarking procedure. In particular, 922 articles were analysed in order to present a broad and complete revision of the theme and 128 of them were clusterized according to the benchmarking procedure adopted. Revising this collection of publications distributed between 1963 and 2019, 49 clouds of papers belonging to the same instance were collected, divided for type of objective function and input data assumed. This collection shows how many and which publications have used instances for the benchmarking analysis, that is essential to test the methodological rigour of a given approach compared to others. The results reveal that in literature only a small number of authors compare their method with a significant number of instances. This evidence therefore suggests that the benchmarking method adopted until now cannot be considered sufficiently robust and has to be improved. Moreover, further developments could include the comparison of the results obtained through other databases (such as web of science), to provide an overarching analysis of the extant literature.

\section{References}

Ahmadi, A., \& Akbari Jokar, M.R. (2016). An efficient multiple-stage mathematical programming method for advanced single and multi-floor facility layout problems. Applied Mathematical Modeling, 40(9-10), 5605-5620.

Aiello, G., Enea, M., \& Galante, G. (2002). An integrated approach to the facilities and material handling system design. International Journal of Production Research, 40(15), 4007-4017.

Aiello, G., La Scalia, G., \& Enea, M. (2013). A non dominated ranking Multi Objective Genetic Algorithm and electre method for unequal area facility layout problems. Expert Systems with Applications, 40(12), 4812-4819.

Allahyari, M.Z., \& Azab, A. (2018). Mathematical modeling and multi-start search simulated anneling for unequal-area facility layout problem. Expert Systems with applicattions, 91(C), 46-62.

Amaral, A.R.S. (2009). A new lower bound for the single row facility layout problem. Discrete Applied Mathematics, 157(1), 183-190.

Amaral, A.R.S. (2008). An exact approach to the one-dimensional facility layout problem. Operation Research, 56(4), 1026-1033.

Amaral ARS. (2006). On the exact solution of a facility layout problem. European Journal of Operation Research, 173 (2), 508-518.

Amaral, A.R.S. (2013). Optimal solutions for the double row layout problem. Optimization Letters, 7(2), 407-413.

Amaral, A.R.S., \& Letchford, A.N. (2011). A polyhedral approach to the single row facility layout problem. Mathematical Programming Series A, 141(1-2), 453-477.

Anjos, M. F., \& Vannelli, A., (2008). Computing Globally Optimal Solutions for Single-Row Layout Problems Using Semidefinite Programming and Cutting Planes. INFORMS Journal On Computing, 20(4), 611-617.

Anjos, M.F., \& Vannelli A. (2006). A new mathematical-programming framework for facility-layout design. INFORMS Journal on Computing, 18(1), 111-118.

Anjos, M.F., \& Yen, G. (2009). Provably near-optimal solutions for very large single-row facility layout problems. Optimisation Methods and Software, 24(4-5), 805-817. 
Anjos, M.F., Kennings, A., \& Vannelli, A. (2005). A semidefinite optimization approach for the singlerow layout problem with unequal dimensions. Discrete Optimization, 2(30), 113-122.

Armour, G.C., \& Buffa E.S. (1963). A heuristic algorithm and simulation approach to relative location of facilities. Management Science, 9 (2), 294-309.

Azevedo, M.M., Crispim, J.A., \& de Sousa, J.P. (2017). A dynamic multi objective approach for the reconfigurable multi facility layout problem. Journal of Manufacturing Systems, 42, 140-152.

Azimi, P., \& Charmchi, H.R. (2012). A new optimization via simulation approach for dynamic facility layout problem with budget constraints. Modelling and Simulation in Engineering, 2012, 1-9.

Balakrishnan, J., Cheng, C.H., Conway, D.G., \& Lau, C.M. (2003). A hybrid genetic algorithm for the dynamic plant layout problem. International Journal of Production Economics, 86(2), 107-120.

Balakrishnan, J., \& Cheng, C.H. (2000). Genetic search and the dynamic layout problem. Computers and Operations Research, 27(6), 587-593.

Banerjee, P., Zhou, Y., Krishnasami, K., \& Montreuil, B. (1997). Genetically assisted optimization of cell layout and material flow path skeleton. IIE Transactions, 29(4), 277-291.

Baykasoglu, A., Dereli, T., \& Sabuncu, I. (2006). An ant colony algorithm for solving budget constrained and unconstrained dynamic facility layout problems. Omega, 34(4), 385-396.

Baykasoglu, A., \& Gindy, N. N. Z. (2001). A simulated annealing algorithm for dynamic layout problem. Computers \& Operations Research, 28(14), 1403-1426.

Bazaraa, M.S. (1975). Computerized layout design: a branch and bound approach, A I I E Transactions, 7(4), 432-438.

Bernardi S., \& Anjos M.F. (2012). A two-stage mathematical-programming method for the multi-floor facility layout problem. Journal of Operation Research Society, 64(3), 352-364.

Bozer, Y.A., \& Meller, R.D. (1997). A re-examination of the distancebased facility layout problem. IIE Transactions, 29(7), 549-560.

Bozer, Y.A., Meller, R.D., \& Erlebacher, S.J. (1994). An improvement-type layout algorithm for single and multiple-floor facilities. Management Science, 40(7), 918-932.

Bozer, Y.A., \& Wang, C.T. (2012). A graph-pair representation and MIPmodel- based heuristic for the unequal-area facility layout problem. European Journal of Operation Research, 218(2), 382-391.

Bozer, Y.A., \& Meller, R. D., Erlebacher, S. J. (1994). Improvement-type layout algorithm for single and multiple-floor facilities. Management Science, 40(7), 918-932.

Bozorgi, N., Abedzadeh, M., \& Zeinali, M. (2015). Tabu search heuristic for efficiency of dynamic facility layout problem. International Journal of Advanced Manufucturing Technology, 77(1-4), 689703.

Burkard, R.E., Karisch, S., \& Rendl, F. (1991). QAPLIB - A Quadratic Assignment Problem Library, European Journal of Operational Research, 55(1), 115-119.

Castillo, I., \& Westerlund, T. (2005). An $\varepsilon$-accurate model for optimal unequal-area block layout design. Computers \& Operation Research, 32(3), 429-447.

Castillo, I., Westerlund, J., Emet, S., \& Westerlund, T. (2005). Optimization of block layout design problems with unequal areas: A comparison of MILP and MINLP optimization methods. Computers \& Chemical Engineering, 30(1), 54-69.

Chen, C.W., \& Sha, D.Y. (1999). A design approach to the multi-objective facility layout problem. International Journal of Production Research, 37(5), 1175-1196.

Chen, G.Y. (2013). A new data structure of solution representation in hybrid ant colony optimization for large dynamic facility layout problems. International Journal of Production Economic, 142(2), 36237.1

Conway, D.G., \& Venkataramanan, M.A. (1994). Genetic search and the dynamic facility layout problem. Computers \& Operations Research, 21(8), 955-960.

Das, S. K. (1993). A facility layout method for flexible manufacturing systems. International Journal of Production Research, 31(2), 279-297.

Datta, D., Amaral, A.R.S., \& Figueira, J.R. (2011). Single row facility layout problem using a permutation-based genetic algorithm. European Journal of Operational Research, 213(2), 388-394. 
Deb, S.K., \& Bhattacharyya, B. (2005). Solution of facility layout problems with pickup/drop-off locations using random search techniques. International Journal of Production Research, 43(22), 4787-4812.

Derakhshan Asl, A., \& Wong, K. Y. (2017). Solving unequal-area static and dynamic facility layout problems using modified particle swarm optimization. Journal of Intelligent Manufacturing, 28(6), 1317-1336.

Drira, A., Pierreval, H., \& Hajri-Gabouj S. (2013). Design of a robust layout with information uncertainty increasing overtime: a fuzzy evolutionary approach. Engineering Application of Artificial Intelligence, 12(1), 45-60.

Drira, A., Pierreval, H., \& Hajri-Gabouj, S. (2007). Facility layout problems: A survey. Annual Reviews in Control, 31(2), 255-267.

Dunker, T., Radons, G., \& Westkämper, E. (2003). A coevolutionary algorithm for a facility layout problem. International Journal of Production Research, 41(15), 3479-3500.

Dutta, K.N., \& Sahu, S. (1982). A multi-goal heuristic for facilities design problems: MUGHAL. International Journal of Production Research, 20(2), 147-154.

Enea, M., Galante, G., \& Panascia E. (2005). The facility layout problem approached using a fuzzy model and a genetic search. Journal of Intelligence Manufacturing, 16(3), 303-316.

Erel, E., Ghosh, J.B., \& Simon, J.T. (2003). New heuristic for the dynamic layout problem. Journal of the Operational Research Society, 54(12), 1275-1282.

Feng, J., \& Che, A. (2018). Novel integer linear programming models for the facility layout problem with fixed-size rectangular departments. Computers \& Operations Research, 95, 163-171.

Goncalves, F.J, \& Resende, M.G.C. (2015). A biased randomkey genetic algorithm for the unequal area facility layout problem. European Journal of Operation Research, 246(1), 86-107.

Fortenberry, J.C, \& Cox, J.F. (1985). Multiple criteria approach to the facilities layout problem. International Journal of Production Research, 23(4), 773-782.

Garces-Perez, J., Schoenefeld, D.A., \& Wainwright, R.L. (1996). Solving facility layout problems using genetic programming, Proceedings of the First Annual Conference, MIT Press Cambrige, Standorf, California, July 28-31, 1986, 182-190.

Gau, K.Y., \& Meller, R.D. (1999). An iterative facility layout algorithm. International Journal of Production Research, 37(16), 3739-3758.

Goetschalckx, M. (1992). An interactive layout heuristic based on hexagonal adjacency graphs. European Journal of Operation Research, 63(2), 304-321.

Guan, J., \& Lin, G. (2016). Hybridizing variable neighborhood search with ant colony optimization for solving the single row facility layout problem. European Journal of Operation Research, 248(3), 899909.

Harmonsky, C.M., \& Tothero, G.K. (1992). A multi-factor plant layout methodology. International Journal of Production Research, 30(8), 1773-1789.

Hassan, M.D.M., Hogg, G.L., \& Smith, D.R. (1986). Shape: a construction algorithm for area placement evaluation. International Journal of Production Research, 24(5), 1283-1295.

Heragu, S.S., \& Kusiak, A. (1988). Machine layout problem in flexible manufacturing systems. Operations Research, 36(2), 258-268.

Heragu, S.S. (1997). Facilities design. Boston: BWS.

Heragu, S.S., \& Alfa, A.S. (1992). Experimental analysis of simulated annealing based algorithms for the facility layout problem. European Journal of Operational Research, 57(2), 190-202.

Heragu, S.S., \& Kusiak, A. (1991). Efficient models for the facility layout problems. European Journal of Operational Research, 53(1), 1-13.

Hosseini Nasab, H., \& Emami, L. (2013). A hybrid particle swarm optimization for dynamic facility layout problem. International Journal of Production Research, 51(14), 4325-4335.

Hosseini, S.M., Al Khaled, A., \& Vadlamani, S. (2014). Hybrid imperialist competitive algorithm, variable neighborhood search, and simulated annealing for dynamic facility layout problem. Neural Computing \& Applications, 25(7-8), 1871-1885. 
Hosseini-Nasab, H., Fereidouni, S., Fatemi Ghomi, S.M.T., \& Fakhrzad M.B. (2018). Classification of facility layout problems: a review study. International Journal of Advanced Manufacturing Technology, 94(1-4), 957-977.

Hu, G.H., Chen, Y.P., Zhou, Z.D., \& Fang, H.C. (2007). A genetic algorithm for the inter-cell layout and material handling system design. International Journal of Advanced Manufacturing Technology, 34(11-12), 1153-1163.

Hungerlander, P., \& Anjos, M.F. (2015). A semidefinite optimization based approach for global optimization of multi-row facility layout. European Journal of Operational Research, 245(1), 46-61.

Hungerlander, P. (2014). Single row equidistant facility layout as a special case of single row facility layout. International Journal of Production Research, 52(5), 1257-1268.

Hungerländer, P., \& Rendl, F. (2011). Semidefinite relaxations of ordering problems. Mathematical Programming B, 140(1), 77-97.

Hungerländer, P., \& Rendl, F. (2013). A computational study and survey of methods for the single-row facility layout problem. Computational Optimization and Applications, 55(1), 1-20.

Imam, M.H., \& Mir, M. (1989). Nonlinear programming approach to automated topologyoptimization. Computer aided design, 21(2), 107-115.

Ingole, S., \& Singh, D. (2016) Unequal area, fixed shape facility layout problems using the firefly algorithm. Engineering Oprimization, 49(7), 1097-1115.

Jankovits, I., Luo, C., Anjos, M.F., \& Vannelli, A. (2011). A convex optimization framework for the unequal-areas facility layout problem. European Journal of Operational Research, 214(2), 199-215.

Jerin Leno, I., Saravana Sankar, S., \& Ponnambalam, S.G. (2016). An elitist strategy genetic algorithm using simulated annealing algorithm as local search for facility layout design. International Journal of Advanced Manufacturing Technology, 84(5-8), 787-799.

Jolai, F., Tavakkoli-Moghaddam, R., \& Taghipour, M. (2012). A multiobjective particle swarm optimization algorithm for unequal sized dynamic facility layout problem with pickup/drop-off locations. International Journal of Production Research, 50(15), 4279-4293.

Kado, K. (1995). An investigation of genetic algorithms for facility layout problems. Master's Thesis, University of Edinburgh.

Kaku, B.K., \& Mazzola, J.B. (1997) A tabu search heuristic for the dynamic plant layout problem. INFORMS Journal on Computing, 9(4), 374-384.

Kalita, Z., \& Datta, D. (2018). A constrained single row facility layout problem. The international journal of advanced manufacturing technology, 98(5-8), 2173-2184.

Kamoun, M., \& Yano, C.A. (1996). Facility layout to support just-in time. Transportation Science, 30(4), 315-329.

Khalil, T.M. (1973). Facilities relative allocation technique (FRAT). International Journal of Production Research, 11(2), 183-194.

Kaveh, M., Majazi Dalfard, V., \& Amiri, S. (2014) A new intelligent algorithm for dynamic facility layout problem in state of fuzzy constraints. Neural Computing \& Applications, 24(5),1179-1190.

Klausnitzer, A., \& Lasch, R. (2019). Optimal facility layout and material handling network design. Computers \& Operations Research, 103, 237-251.

Komarudin, K., \& Wong, Y. (2010). Applying ant system for solving unequal area facility layout problems. European Journal of Operation Research, 202(3), 730-746.

Konak, A., Kulturel-Konak, S., Norman, B.A., \& Smith, A.E. (2006). A new mixed integer programming formulation for facility layout design using flexible bays. Operations Research Letters, 34(6), 660672.

Koopmans, T. C., \& Beckmann, M. (1957). Assignment problems and the location of economic activities. Econometrica, 25(1), 53-76.

Kothari, R., \& Ghosh, D. (2014). A scatter search algorithm for the single row facility layout problem. Journal of Heuristics, 20(2), 125-142.

Kothari, R., \& Ghosh, D. (2013b). Insertion based Lin-Kernighan heuristic for single row facility layout. Computers \& Operation Research, 40(1), 129-136. 
Kothari, R., \& Ghosh D. (2013a). Tabu search for the single row facility layout problem using exhaustive 2-opt and insertion neighborhoods. European Journal of Operation Research, 224(1), 93-100.

Kouvelis, P., Kurawarwala, A. A., \& Gutierrez, G. J. (1992). Algorithms for robust single and multiple period layout planning for manufacturing systems. European Journal of Operations Research, 63(2), 287-303.

Kulturel Konak, S., \& Konak, A. (2015). A large-scale hybrid simulated annealing algorithm for cyclic facility layout problems. Engineering Optimization, 47(7), 963-978.

Kulturel-Konak, S. (2012). A linear programming embedded probabilistic tabu search for the unequalarea facility layout problem with flexible bays. European Journal of Operational Research, 223(3), 614-625.

Kulturel-Konak, S., \& Konak, A. (2011b). A new relaxed flexible bay structure representation and particle swarm optimization for the unequal area facility layout problem. Engineering Optimization, 43(12), 1263-1287.

Kulturel-Konak, S., \& Konak, A. (2013). Linear programming based genetic algorithm for the unequal area facility layout problem. International Journal of Production Research, 51(14), 4302-4324.

Kulturel-Konak, S., \& Konak, A. (2011a). Unequal area flexible bay facility layout using ant colony optimization. International Journal of Production Research, 49(7), 1877-1902.

Kumar, K.R., Hadjinicola, G. C., \& Lin, T.L. (1995). A heuristic procedure for the single row facility layout problem. European Journal of Operational Research, 87(1), 65-73.

Kusiak, A., Heragu, S.S. (1987). The facility layout problem. European Journal of Operational Research, 29(3), 229-251.

Lacksonen, T.A., \& Enscore, E.E. (1993). Quadratic assignment algorithms for the dynamic layout problem. International Journal of Production Research, 31(3), 503-517.

La Scalia, G., Micale, R., Giallanza, A., \& Marannano, G. (2019). Firefly algorithm based upon slicing structure encoding for unequal facility layout problem. International Journal of Industrial Engineering Computations, 10(3), 349-360.

Leno, I.J., Sankar, S.S., \& Ponnambalam, S.G. (2018). MIP model and elitist strategy hybrid GA-SA algorithm for layout design. Journal of Intelligent Manufacturing, 29(2), 369-387.

Liu, X., \& Sun, X. (2012). A multi-improved genetic algorithm for facility layout optimization based on slicing tree, International Journal of Production Research, 50(18), 5173-5180.

Liu, J., \& Liu, J. (2019). Applying multi-objective ant colony optimization algorithm for solving the unequal area facility layout problems. Applied Soft Computing Journal, 74, 167-189.

Liu, J., Zhang, H., He, K., \& Jiang, S. (2018). Multi-objective particle swarm optimization algorithm based on objective space division for the unequal-area facility layout problem. Expert Systems with Applications, 102(C), 179-192.

Liu, Q., \& Meller, R.D. (2007). A sequence-pair representation and MIP-model-based heuristic for the facility layout problem with rectangular departments. IIE Transactions, 39(4), 377-394.

Logendrana, R., \& Kriausakula, T. (2006). A methodology for solving the unequal area facility layout problem using distance and shapebased measures. International Journal of Production Research, 44(7), 1243-1272.

Love, R.F., \& Wong, J. Y. (1976). On solving a one-dimensional space allocation problem with integer programming. Information Processing and Operations Research (INFOR), 14(2), 139-143.

Matai, R., Singh, S.P., \& Mittal, M.L. (2013). A non-greedy systematic neighborhood search heuristic for solving facility layout problem. International Journal of Advanced Manufacturing Technology, 68(5-8), 1665-1675.

Matai, R. (2015). Solving multi-objective facility layout problem by modified simulated annealing. Applied Mathematics and Computation, 261(C), 302-311.

Matsuzaki, K., Irohara, T., \& Yoshimoto, K. (1999). Heuristic algorithm to solve the multi-floor layout problem with the consideration of elevator utilization. Computers \& Industrial Engineering, 36(2), 487-502. 
Mazinani, M., Abedzadeh, M., \& Mohebali, N. (2013). Dynamic facility layout problem based on flexible bay structure and solving by genetic algorithm. International Journal of Advanced Manufacturing Technology, 65(5-8),929-943.

McKendall, A.R. Jr., \& Hakobyan, A. (2010). Heuristics for the dynamic facility layout problem with unequal-area departments. European Journal of Operation Research, 201(1), 171-182.

McKendall, A.R. Jr., \& Shang J. (2006). Hybrid ant systems for the dynamic facility layout problem. Computers \& Operations Research, 33(3), 790-803.

McKendall, A.R. Jr., Shang, J., \& Kuppusamy, S. (2006). Simulated annealing heuristics for the dynamic facility layout problem. Computers \& Operations Research, 33(8), 2431-2444.

Meller, R.D., \& Bozer, Y.A. (1996). A new simulated annealing algorithm for the facility layout problem. International Journal of Production Research, 34(6), 1675-1692.

Meller R., Narayanan V., Vance P. (1999). Optimal facility layout design. Operations Research Letters, 23(3-5), 117-127.

Meller, R.D., Chen, W., \& Sherali, H.D. (2007). Applying the sequence-pair representation to optimal facility layout designs. Operations Research Letters, 35(5), 651-659.

Meller, R.D. (1992). Layout algorithms for single and multiple floor facilities. Department of Industrial and Operations Engineering, The University of Michigan.

Mir, M., \& Imam, M.H. (2001). A hybrid optimization approach for layout design unequal area facilities. Computers \& Industrial Engineering, 39(1-2), 49-63.

Montreuil, B., Brotherton, E., Ouazzani, N., \& Nourelfath, M. (2004). Ant zone layout metaheuristic: coupling zone-based layout optimization, ant colony system and domain knowledge, Canada Research Chair in Enterprise Engineering.

Neghabi, H., Eshghi, K., \& Salmani, M.H. (2014). A new model for robust facility layout problem. Information Sciences, 278, 498-509.

Neghabat, F. (1974). An efficient equipment layout algorithm, Operations Research, 22(3), 622-628.

Nematian, J. (2014). A robust single row facility layout problem with fuzzy random variables. International Journal of Advanced Manufacturing Technology, 72(1-4), 255-267.

Ning, X., \& Li, P. (2017). A cross entropy approach to the single row facility layout problem. International Journal of Production Research, 56(11), 3781-3794.

Nugent, C.E., Vollmann, T.E., \& Runl, J. (1968). An experimental comparison of techniques for the assignment of facilities to locations. International Journal of Production Research, 16(1), 150-173.

Obata, T. (1979). Quadratic Assignment Problems: Evaluation of Exact and Heuristic Algorithms, Ph.D. Dissertation, Rensselaer Polytechnic Institute.

Ou-Yang, C., \& Utamima, A. (2013). Hybrid estimation of distribution algorithm for solving single row facility layout problem. Computers \& Industrial Engineering, 66(1), 95-103.

Ozcelik, F. (2013). A hybrid genetic algorithm for the single row layout problem. International Journal of Production Research, 50(20), 5872-5886.

Palubeckis, G. (2017). Single row facility layout using multi start simulated anneling. Computers \& Industrial Engineering, 103, 1-16.

Palubeckis, G. (2012). A branch and bound algorithm for the singlerow equidistant facility layout problem. OR Spectrum, 34(1), 1-21.

Palubeckis, G. (2015). Fast local search for single row facility layout. European Journal of Operation Research, 246(3), 800-814.

Pillai, V.M., Hunagund, I.B., \& Krishnan, K.K. (2011). Design of robust layout for dynamic plant layout problem. Computers in Industry, 61(3), 813-823.

Pourvaziri, H., \& Naderi, B. (2014). A hybrid multi-population genetic algorithm for the dynamic facility layout problem. Applied Soft Computing, 24(C), 457-469.

Rajasekharan, M., Peters, B.A., \& Yang, T. (1998). A genetic algorithm for facility layout design in flexible manufacturing system. International Journal of Production Research, 36(1), 95-110.

Ramkumar, A.S., Ponnambalam, S.G., \& Jawahar, N. (2009b). A new iterated fast local search heuristic for solving QAP formulation in facility layout design. Robotics \& Computer Integrated Manufacturing, 25(3), 620-629. 
Ramkumar, A.S., Ponnambalam, S.G., \& Jawahar, N. (2009a). A population-based hybrid ant system for quadratic assignment formulations in facility layout design. International Journal of Advanced Manufacturing Technololgy, 44 (5-6), 548-558.

Ripon, K.S.N., Khan, K.N., Glette, K., Hovin, M., \& Torresen, J. (2011a). Using pareto- optimality for solving multi-objective unequal area facility layoutproblem, Krasnogor, N., \& Lanzi, P.L. (Eds.), Proceedings of the 13th Annual Conference on Geneticand Evolutionary Computation GECCO'11, ACM, New York, USA.

Ripon, K.S.N., Glette, K., Hovin, M., \& Torresen, J. (2011b). Dynamic facility layout problem under uncertainty: a Pareto-optimality based multi-objective evolutionary approach. Central European Journal of Computer Science, 1(4), 375-386.

Ripon, K.S.N., Glette, K., Khan, K.N., Hovin, M., \& Torresen, J. (2013). Adaptive variable neighborhood search for solving multiobjective facility layout problems with unequal area facilities. Swarm and Evolutionary Computation, 8, 1-12.

Rosenblatt, M.J. (1986). The dynamics of plant layout. Management Science, 32(1), 76-86.

Rosenblatt, M.J. (1979). The facilities layout problem: A multi-goal approach. International Journal of Production Research, 17(4), 323-332.

Rubio-Sanchez, M., Gallego, M., Gortazar, F., \& Duarte, A. (2016). GRASP with path relinking for the single row facility layout problem. Knowledge-Based Systems, 106(C), 1-13.

Saberi, E., \& Azimi, P. (2013). An efficient hybrid algorithm for dynamic facility layout problem using simulation technique and PSO. Economic Computation \& Economic Cybernetics Studies \& Research, 47(4), 1-17.

Sahin, R. (2011). A simulated annealing algorithm for solving the bi-objective facility layout problem. Expert Systems with Applications, 38(4), 4460-4465.

Sahin, R., Ertogral, K., \& Turkbey, O. (2010). A simulated annealing heuristic for the dynamic layout problem with budget constraint. Computers \& Industrial Engineering, 59(2), 308-313.

Samanta, S., Philip, D., \& Chakraborty, S. (2018). Bi-objective dependent location quadratic assignment problem: Formulation and solution using a modified artificial bee colony algorithm. Computers \& Industrial Engineering, 121, 8-26.

Samarghandi, H., \& Eshghi, K. (2010). An efficient tabu algorithm for the single row facility layout problem. European Journal of Operation Research, 205(1), 98-105.

Samarghandi, H., Taabayan, P., \& Jahantigh, F.F. (2010). A particle swarm optimization for the single row facility layout problem. Computers \& Industrial Engineering, 58(4), 529-534.

Saraswat, A., Venkatadri, U., \& Castillo, I. (2015). A framework for multi-objective facility layout design. Computers \& Industrial Engineering, 90(C), 167-176.

Schnecke, V., \& Vornberger, O. (1997). Hybrid genetic algorithms for constrained placement problems. IEEE Transactions on Evolutionary Computation, 1(4), 266-277.

Scholz, D., Petrick, A., \& Domschke, W. (2009). STaTS: a slicing treen and tabu search based heuristic for the unequal area facility layout problem. European Journal of Operation Research, 197(1), 166178.

Scriabin, M., \& Vergin, R.C. (1985). A cluster analytic approach to facility layout. Management Science, 31(1), 33-49.

Sherali, H.D., Fraticelli, B.M.P., Meller, R.D. (2003). Enhanced model formulations for optimal facility layout. Operations Research, 51(4),629-644.

Simmons, D.M. (1969). One-dimensional space allocation: An ordering algorithm. Operations Research, $17(5), 812-826$.

Singh, S.P., \& Singh, V.K. (2010). An improved heuristic approach for multi-objective facility layout problem. International Journal of Production Research, 48(4), 1171-1194.

Singh, S.P., \& Sharma, R.R. (2008). Two-Level Modified Simulated Annealing Based Approach for Solving Facility Layout Problem. International Journal of Production Research, 46(13), 3563-3582.

Solimanpur, M., Vrat, P., \& Shankar, R. (2005). An ant algorithm for the single row layout problem in flexible manufacturing systems. Computers \& Operations Research, 32(3), 583-598. 
Suresh, G., \& Sahu, S. (1993). Multi objective facility layout using simulated annealing International Journal of Production Economics, 32(2), 239-254.

Tam, K.Y. (1992). A simulated annealing algorithm for allocating space to manufacturing cells. International Journal of Production Research, 30(1), 63-87.

Tam, K.Y., \& Li, S.G. (1991). A hierarchical approach to the facility layout problem. International Journal of Production Research, 29(1), 165-184.

Tate, D.M., \& Smith, A.E. (1995). Unequal-area facility layout by genetic search. IIE Transactions, 27(4), 465-472.

Tayal, A., \& Singh, S.P. (2018). Integrating big data analytic and hybrid firefly-chaotic simulated annealing approach for facility layout problem. Annals of Operations Research, 270(1-2), 489-514.

Teo, Y.T., \& Ponnambalam, S.G. (2008). A hybrid ACO/PSO heuristic to solve single row layout problem. In IEEE International Conference on Automation Science and Engineering, Arlington, VA, USA, 23-26 August 2008, 597-602.

Tompkins, J. A., White, J. A., Bozer, Y.A., Frazelle, E. H., Tanchoco, J. M., \& Trevino, J. (1996). Facilities planning. New York: Wiley.

Tsuchiya, K., Bharitkar, S., \& Takefuji, Y. (1996). A neural network approach to facility layout problems, European Journal of Operation Research, 89(3), 556-563.

Turanoğlu, B., \& Akkaya, G. (2018). A new hybrid heuristic algorithm based on bacterial foraging optimization for the dynamic facility layout problem. Expert Systems with Applications, 98, 93-104.

Ulutas, B.H., \& Islier, A.A. (2009). A clonal selection algorithm for dynamic facility layout problems. Journal of Manufacturing Systems, 28(4), 123-131.

Ulutas, B.H., \& Kulturel-Konak, S. (2012). An artificial immune system based algorithm to solve unequal area facility layout problem. Expert System with Applications, 39(5), 5384-5395.

van Camp, D.J., Carter, M.W., \& Vannelli, A. (1991). A nonlinear optimization approach for solving facility layout problems. European Journal of Operational Research, 57(2), 174-189.

Van Eck, N.J., \& Waltman, L. (2010). Software survey: VOSviewer, a computer program for bibliometric mapping. Scientometrics, 84(2), 523-538.

van Nunen, K., Li, J., Reniers, G., \& Ponnet, K. (2017). Bibliometric analysis of safety culture research. Safety Science, 108, 248-258.

Wang, M.J., Hu, M.H., \& Ku, M.M.H. (2005). A solution to the unequal area facilities layout problem by genetic algorithm. Computers in Industry, 56(2), 207-220.

Welgama, P.S., \& Gibson, P.R. (1993). A construction algorithm for the machine layout problem with fixed pick-up and drop-off points. International Journal of Production Research, 31(11), 2575-2589.

Wilhelm, M.R., \& Ward, T.L. (1987). Solving quadratic assignment problems by simulated annealing. IIE Transactions, 19(1), 107-119.

Wong, K.Y., Komarudin. (2010). Solving facility layout problems using flexible bay structure representation and ant system algorithm. Expert System with Applications, 37(7), 5523-5527.

$\mathrm{Wu}, \mathrm{Y}$., \& Appleton, E. (2002). The optimization of block layout and aisle structure by a genetic algorithm. Computers \& Industrial Engineering, 41(4), 371-387.

Xie, W, \& Sahinidis, NV. (2008). A branch and bound algorithm for the continuous facility layout problem. Computers \& Chemical Engineering, 32(4-5), 1016-1028.

Yang, T., \& Hung, C.C. (2007). Multiple-attribute decision making methods for plant layout design problem. Robotics and Computer-Integrated Manufacturing, 23(1), 126-137.

Yang, T., \& Peters, B. (1998). Flexible machine layout design for dynamic and uncertain production environments. European Journal of Operational Research, 108(1), 49-64.

Yu, J., \& Sarker, B.R. (2003). Directional decomposition heuristic for a linear machine- cell location problem. European Journal of Operational Research, 149(1), 142-184. 
(C) 2019 by the authors; licensee Growing Science, Canada. This is an open access article distributed under the terms and conditions of the Creative Commons Attribution (CCBY) license (http://creativecommons.org/licenses/by/4.0/). 